\title{
Investigating Transgenic Corn Hybrids as a Method for Mycotoxin Control
}

\author{
Hamed K. Abbas ${ }^{1}$, Nacer Bellaloui' ${ }^{2}$, H. Arnold Bruns ${ }^{3}$ \\ ${ }^{1}$ Biological Control of Pests Research Unit, USDA-ARS, Stoneville, USA \\ ${ }^{2}$ Crop Genetic Research Unit, USDA-ARS, Stoneville, USA \\ ${ }^{3}$ Crop Production Systems Research Unit, USDA-ARS, Stoneville, USA \\ Email: hamed.abbas@ars.usda.gov
}

Received 11 December 2015; accepted 23 January 2016; published 26 January 2016

Copyright (C) 2016 by authors and Scientific Research Publishing Inc.

This work is licensed under the Creative Commons Attribution International License (CC BY). http://creativecommons.org/licenses/by/4.0/

(c) () Op Open Access

\section{Abstract}

Transgenic Bt corn hybrids have been available for more than $\mathbf{1 0}$ years and are known to control specific insects. More recently, so-called "stacked-gene" hybrids, have been released with multiple insect resistance genes and genes for herbicide resistance, resulting in up to 6 traits per plant. Because insect damage can lead to increased levels of mycotoxins, such as aflatoxins and fumonisin, we designed a study to compare ten commercially available corn hybrids, two non-transgenic, four with both herbicide and insect tolerance (stacked-gene) and four with glyphosate tolerance only to determine if any hybrid class had the advantage of reduced mycotoxin contamination. The experiment was carried out in the Mississippi State University Delta Research Extension fields in Stoneville, MS for two years in fine sandy loam and clay soil. Rows were either inoculated at the V10 stage of growth with toxigenic Aspergillus flavus K54 (NRRL 58987, isolated from corn kernels in Mississippi), grown on wheat, and applied at a rate of $22.42 \mathrm{~kg} / \mathrm{ha}$ or allowed to become naturally infected with disease-producing fungi, including various Fusarium and other Aspergillus spp. Mycotoxin production differed according to the soil type with lower levels detected in the hybrids planted in clay soil vs. sandy soil. However, no significant differences in mycotoxin production were found amongst the hybrid classes. More research is needed to identify conditions under which transgenic hybrids might produce higher yields and lower mycotoxin levels. Presently, selection of transgenic hybrids will not replace integrated strategies of biocontrol, host plant resistance, or good crop management practices for achieving adequate mycotoxin control in corn.

\section{Keywords}

Stacked-Gene Corn, Hybrids, Soil Type, Mycotoxins, Aflatoxin, Fumonisin 


\section{Introduction}

The use of transgenic crops has become increasingly common over the past 10 years in the U.S. and some areas around the world [1]. Most of these transgenic crops such as corn, soybean, and cotton, were generated to manage agricultural pests including insects, weeds, and to some extent diseases. Initially, transgenics started with a single trait to control a specific pest [2]-[11]. Recently, new technology has emerged and generated crops with multiple engineered traits which are called "stacked-gene hybrids" enabling them to control more than one agricultural pest [12] [13]. Evaluation of transgenic corn hybrids in regard to mycotoxin management has not been well established, especially in regard to aflatoxin and fumonisin. While Bt corn has demonstrated some mediating effect on fumonisin, aflatoxin, and trichocenes, no transgenic hybrids have been developed specifically to lower mycotoxin contamination [1] [14]-[16]. The increased level of mycotoxins, due to insect damage, was thought to be due to the fact that insect feeding allows fungi to enter the plant and produce mycotoxins [17]-[20]. Research has shown that fumonisin levels are reduced in Bt corn, but no conclusions could be drawn about possible reductions in aflatoxins [1]. Corn contaminated with mycotoxins may lead to major food safety issues, production losses and grain waste [21]. Aflatoxins are a group of chemical compounds produced primarily by Aspergillus flavus, as well as other Aspergillus spp. Aflatoxins and fumonisins can both be serious problems in the southern U.S., while fumonisins are often more prevalent in more northerly areas of the U.S. [22]-[24].

A number of environmental parameters affect mycotoxin production, including heat, drought, insect infestation and various plant diseases [25]-[31]. When both toxins are found together, the risk of toxicity increases [24] [32]-[34]. Theoretically, stacked-gene hybrids should be beneficial to reduce mycotoxins, as they are formulated to deal with factors affecting mycotoxin production. The objective of this study was to investigate the effect of stacked-gene corn hybrids on the accumulation of fumonisins and aflatoxins, compared to single trait glyphosate resistant and non-transgenic hybrids under irrigated field conditions in the Mississippi Delta, and was part of an experiment previously reporting the yield and economics of three classes of corn hybrids [12].

\section{Materials and Methods}

\subsection{Stacked-Gene Hybrids and Field Conditions}

Ten corn hybrids, four stacked-gene, four glyphosate-tolerant and two non-GMO, were purchased commercially in 2011, and were used in both 2011 and 2012 (Table 1). Between planting seasons, remaining seed were preserved in cold storage $\left(4^{\circ} \mathrm{C}\right)$. The research was conducted at two sites, one a Bosket fine sandy loam (fine-loamy, mixed, active, thermic Mollic Hapludalfs), located on the Mississippi State University Delta Branch Research

Table 1. Conventional and transgenic corn hybrids used in 2011 and 2012 study.

\begin{tabular}{|c|c|c|c|c|}
\hline Hybrid $^{\dagger}$ & Trait branding & Insect traits & Herbicide tolerance & Transformation event \\
\hline 31P41 & & None & None & \\
\hline $33 N 56$ & & None & None & \\
\hline $1615 R$ & RR2 & None & Glyphosate & \\
\hline $31 \mathrm{P} 40$ & RR2 & None & Glyphosate & \\
\hline $33 N 55$ & RR2 & None & Glyphosate & \\
\hline DKC 67-22 & RR2 & None & Glyphosate & \\
\hline $31 \mathrm{G} 96$ & HX1, LL, RR2 & Cry1 F & $\begin{array}{l}\text { Glyphosate, } \\
\text { glufosinate }\end{array}$ & TC1507 \\
\hline 31P42 & HX1, LL, RR2 & Cry1 F & $\begin{array}{l}\text { Glyphosate, } \\
\text { glufosinate }\end{array}$ & TC1507 \\
\hline DKC 66-96 & Genuity VT Triple PRO & Cry1A.105, Cry2 Ab2, Cry3 Bb & Glyphosate & Mon88017 + Mon89034 \\
\hline DKC 67-21 & Genuity VT Triple PRO & Cry1A.105, Cry2 Ab2, Cry3 Bb & Glyphosate & Mon88017 + Mon89034 \\
\hline
\end{tabular}

${ }^{\dagger}$ 31P41 and 33N56 are conventional hybrids; 1615R, 31P40, 33N55, and DKC 67-22 are single trait glyphosate tolerant only hybrids with no Bt; and 31G96, 31P42, DKC 66-96, and DKC 67-21are classed as Stacked-Gene Hybrids with insect and herbicide resistance traits. 
and Extension Center, Stoneville, MS, and the other a Tunica clay (clayey over loamy, smectitic, nonacid, thermic Vertic Haplaquept) on private property $1.5 \mathrm{k}$ north of Elisabeth, MS, U.S.A. Each hybrid was planted in eight row plots (1.4 meter between rows 12 meter long) with a final stand density of approximately 31,000 kernels $\cdot \mathrm{A}^{-1}$. The experiments were planted 7 April 2011 and 29 March, 2012. All experiments were conducted in conventional tillage plots, furrow irrigation was performed, and all other agronomic measurements as previously described by Bruns [12]. Rows 7 and 8 within each plot were inoculated at the V10 stage of growth with toxigenic Aspergillus flavus K54 (NRRL 58987, isolated from corn kernels in Mississippi), grown on wheat, and applied at a rate of $22.42 \mathrm{~kg} / \mathrm{ha}$ [35]. The remaining 6 rows were allowed to become naturally infected with disease-producing fungi, including various Fusarium and other Aspergillus spp.

The mature crop was harvested with a two row combine. The non-inoculated rows were harvested first, and then the inoculated rows were harvested. Two different combines were used; one to harvest the inoculated rows (Gleaner K2, AGCO, Duluth, GA) and the other (Kincaid, Haven, KS) to harvest the non-inoculated rows to prevent cross-contamination. Yield and yield components were determined and previously published [12].

\subsection{Mycotoxin Analysis}

Sub-samples of $2 \mathrm{~kg}$ of kernels from each treatment were pooled, mixed, oven dried at $50^{\circ} \mathrm{C}$ for 3 to $5 \mathrm{~d}$, and ground (20 mesh) using a Romer mill (Union, MO). A representative $50 \mathrm{~g}$ sub-sample was taken and extracted in $250 \mathrm{~mL}$ of $70 \%$ methanol as previously described [23]. Both aflatoxin and fumonisin levels were determined by High-Pressure Liquid Chromatography (HPLC) with post-column derivations as described below.

\subsection{Aflatoxin Determination}

Preparation, cleanup and determination of aflatoxin in samples were performed according to protocols as described in detail previously by Abbas et al. [23]. Briefly, aflatoxin levels were analyzed by WATERS HPLC with post-column photochemical derivation (PHRED) (Aura Industries, New York, NY) and fluorescence detection, containing a WATERS 717 Autosampler. Detection limit of this procedure was $0.1 \mathrm{ng} / \mathrm{g}$, and the standard curve was linear up to $200 \mathrm{ng} / \mathrm{g}$.

\subsection{Fumonisin Determination}

Fumonison samples extracted in 70\% methanol were cleaned up using Bond-Elute SAS columns (Varian, Harbor City, CA) [23] [25] [36]. The columns were washed using $2.5 \mathrm{~mL}$ each of $100 \%$ methanol and $75 \%$ methanol. Next, $2.5 \mathrm{~mL}$ of the sample extract was applied to the column, and washed again with $75 \%$ methanol and $100 \%$ methanol applied to the column. The sample was eluted using $2.5 \mathrm{~mL}$ of $2 \%$ acetic acid in methanol, dried under nitrogen at $50^{\circ} \mathrm{C}$ using a Turbo Vap LV (Biotage, Charlotte, NC), and stored at $-20^{\circ} \mathrm{C}$ until ready for analysis. The clean samples were reconstituted in $1 \mathrm{~mL}$ acetonitrile: water (30:70) and analyzed by HPLC with post-column derivatization according to the method described in [37], Joerg Stroke, Institute for Reference Materials and Measurements, Belgium (Personal communication)] with little modification. Samples to be analyzed for fumonisin were injected onto an Agilent 1200 system consisting of a binary pump, autosampler, and a fluorescence detector equipped with a $150 \mathrm{~mm} \times 4.6 \mathrm{~mm}$ i.d. $5 \mu \mathrm{m}$ Zorbax Eclipse XDB-C18 column at a temperature of $45^{\circ} \mathrm{C}$. A secondary pump (Waters Reagent Manager) was also attached to the system connected in-line after the column and before the detector. This allowed for mixing of the injected sample and a derivatization solution before going to the detector. The detector was set at $335 \mathrm{~nm}$ (excitation) and $440 \mathrm{~nm}$ (emission). The mobile phases for this system were $0.1 \%$ formic acid in water (A) and $0.1 \%$ formic acid in acetonitrile (B) in a gradient at a flow rate of $1.2 \mathrm{~mL} / \mathrm{min}$. for 18 minutes beginning at $68 \%$ A and $32 \%$ B for 8 minutes, switching to $60 \%$ $\mathrm{A}$ and $40 \% \mathrm{~B}$ for 3 minutes, and then back to $68 \% \mathrm{~A}$ and $32 \% \mathrm{~B}$ for the rest of the injection. The post-column reaction solution was prepared using sodium carbonate, boric acid, potassium sulfate, N-Acetyl-L-Cysteine, and o-phthaldialdehyde (OPA) and run at a constant flow rate of $0.45 \mathrm{~mL} / \mathrm{min}$. Standards for this analysis were prepared using fumonisin $\mathrm{B}_{1}$ and $\mathrm{B}_{2}$ (Sigma products F1147 and F3771, respectively) in 30\% acetonitrile in water. The $30 \%$ acetonitrile was used as blanks for the analysis. The limit of quantitation was $0.025 \mathrm{ng} / \mu \mathrm{L}$.

\subsection{Experimental Design and Statistical Analysis}

The experiment was a randomized complete block design with four replicates for each hybrid. Analyses of va- 
riance were conducted using Proc mixed of SAS (9.7) (SAS Institute, Cary, NC). Year, soil, cultivar, and genetic background were considered fixed effects. Replicate (Rep) and Rep (Year) were considered random effects. Residual values shown in Table 5 and Table 6 refer to Restricted Maximum Residual Likelihood (REML), which reflects the total variance of the random parameters in the model.

\section{Results and Discussion}

Hybrid had no significant effect on aflatoxin, but interaction with year (hybrid $\times$ year) or year $\times$ soil $\times$ hybrid was statistically significant (Table 2). Inoculation had significant effects for aflatoxin, but its interactions with the rest of factors (year, soil, and hybrid) did not show significant effects. Although the response of fumonosin was similar to aflatoxin for some factors such as the effects of year, soil, and their interactions (Table 2), fumonisin responded differently to other factors in that cultivar, year $\times$ soil $\times$ cultivar, soil $\times$ Inoc, and year $\times$ cultivar $\times$ Inoc had significant effects (Table 2). The significant effects of year, soil, and their interactions indicated the significant of the environmental factors such as heat, drought, and soil on toxins. The weather data [38] revealed that year 2011 was warmer and drier compared with year 2012 (Figure 1(a) and Figure 1(b)), especially during the reproductive and seed-fill stages. This could be a source of effects on inoculation. The different response of aflatoxin and fumonisin to some factors and their interactions reflects the different sensitivity of each toxin to these factors. Both toxins were significantly influenced by the inoculation, indicating that the level of these toxins in the plant is affected by the disease infection. To further evaluate the effects of the three genetic backgrounds (stacked gene hybrids with multiple Bt genes; Round-up Ready, RR2; and non-transgenic) on aflatoxin and fumonisin levels in seeds, data were analyzed where genetic background was modeled with year, soil, and inoculation (Table 3). The analysis confirmed that year, soil, and their interactions, and Inoc had significant influences on aflatoxin and fumonisin levels. However, genetic background or its interactions had no significant influences on either aflatoxin or fumonisin levels, indicating that inoculation influenced the levels of aflatoxin and fumonisin, but the inoculation effects did not depend on the genetic background.

Table 2. Analysis of variance (F values and P values) for the effects of year, cultivar, soil, and inoculation (Inoc), and their interactions on aflatoxin $(\mu \mathrm{g} / \mathrm{kg})$ and fumonisin $(\mathrm{mg} / \mathrm{kg})$ in corn cultivars (stacked gene hybrids and control) in sandy and clay soils under Mississippi delta condition.

\begin{tabular}{|c|c|c|c|c|c|}
\hline \multirow{2}{*}{ Effect } & \multirow{2}{*}{ Num DF } & \multicolumn{2}{|c|}{ Aflatoxin } & \multicolumn{2}{|c|}{ Fumonisin } \\
\hline & & F Calc. & $\mathrm{P}$ & F Calc. & $\mathrm{P}$ \\
\hline Year & 1 & 33.69 & ${ }^{* * *}$ & 20.70 & ${ }^{* * *}$ \\
\hline Soil & 1 & 50.33 & $* * *$ & 4.93 & $*$ \\
\hline Year $\times$ Soil & 1 & 70.07 & ${ }^{* * *}$ & 18.74 & *** \\
\hline Cultivar & 9 & 0.88 & NS & 5.98 & ${ }^{* * *}$ \\
\hline Year $\times$ Cultivar & 9 & 4.13 & $* * *$ & 4.16 & ${ }^{* * *}$ \\
\hline Soil $\times$ Cultivar & 9 & 3.44 & $* * *$ & 1.25 & NS \\
\hline Year $\times$ Soil $\times$ Cultivar & 9 & 1.48 & NS & 2.20 & * \\
\hline Inoc & 1 & 8.57 & $* *$ & 12.85 & ${ }^{* * *}$ \\
\hline Year $\times$ Inoc & 1 & 0.31 & NS & 0.08 & NS \\
\hline Soil $\times$ Inoc & 1 & 0.79 & NS & 10.64 & ${ }^{* * *}$ \\
\hline Year $\times$ Soil $\times$ Inoc & 1 & 3.09 & NS & 63.68 & $* * *$ \\
\hline Cultivar $\times$ Inoc & 9 & 0.45 & NS & 1.35 & NS \\
\hline Year $\times$ Cultivar $\times$ Inoc & 9 & 0.97 & NS & 0.56 & NS \\
\hline Soil $\times$ Cultivar $\times$ Inoc & 9 & 0.71 & NS & 0.77 & NS \\
\hline Year $\times$ Soil $\times$ Cultivar $\times$ Inoc & 8 & 0.73 & NS & 1.33 & NS \\
\hline Rep (Year) & & 0 & & 0 & \\
\hline Residual & & 23659 & & 4.91 & \\
\hline
\end{tabular}

\footnotetext{
*Significance at $\mathrm{P} \leq 0.05 ;{ }^{* *}$ Significance at $\mathrm{P} \leq 0.01 ;{ }^{* * *}$ Significance at $\mathrm{P} \leq 0.001$.
} 


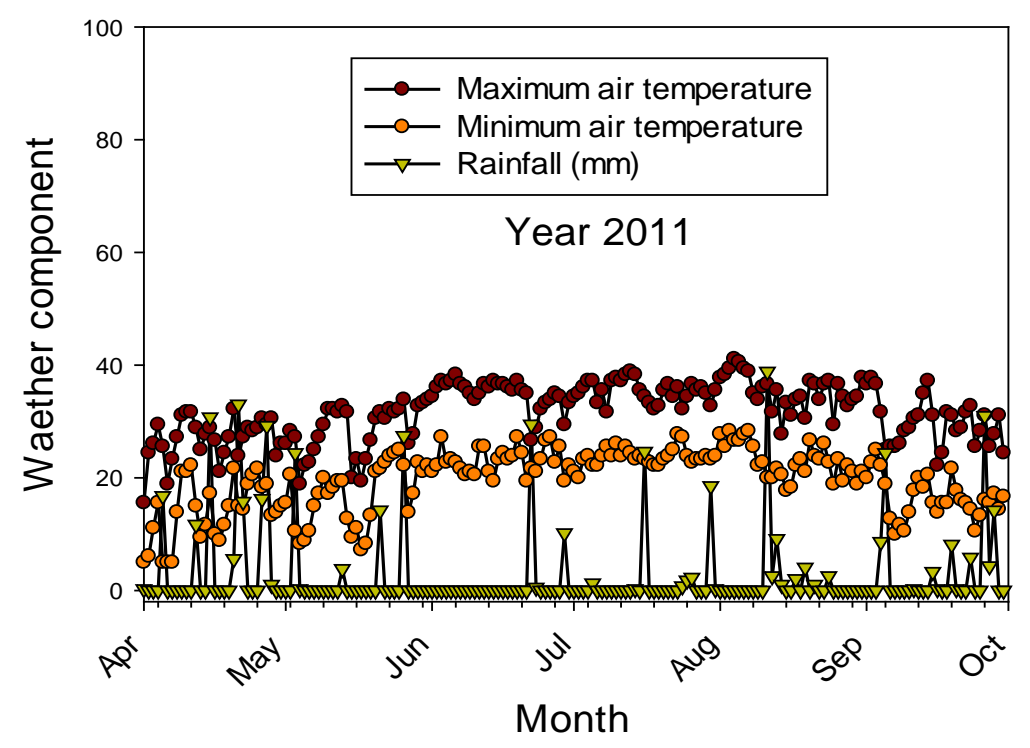

(a)

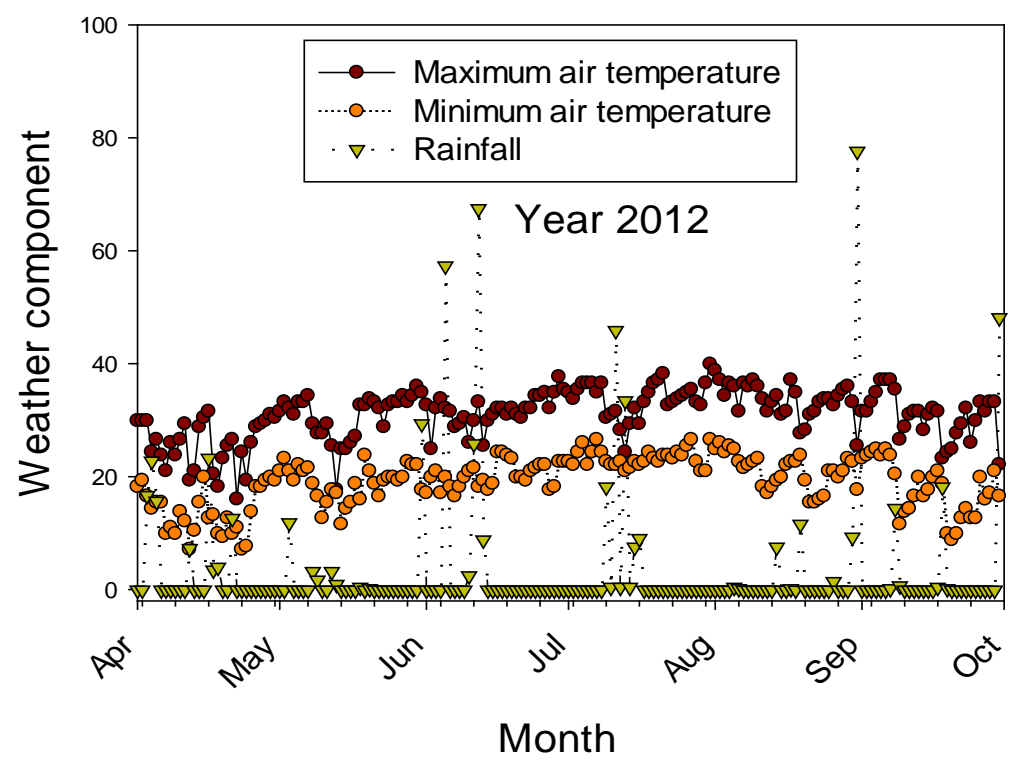

(b)

Figure 1. Weather data for 2011 and 2012 in the Mississippi Delta.

\subsection{Levels of Aflatoxin and Fumonisin in Hybrids}

The levels of aflatoxin in samples from the Tunica clay compared to Bosket FSL are shown in Table 4. Aflatoxin levels observed among samples of the non-inoculated corn of the ten hybrids from the Tunica clay type was variable ranging from $1.4 \mu \mathrm{g} / \mathrm{kg}$ for stacked corn hybrid $31 \mathrm{G} 96$ to $88.9 \mu \mathrm{g} / \mathrm{kg}$ for stacked corn hybrid DK67-21. Aflatoxin levels among the inoculated corn of the same ten hybrids were variable as well ranging from $0.1 \mu \mathrm{g} / \mathrm{kg}$ for RR2 corn hybrid 31P40 to $207.4 \mu \mathrm{g} / \mathrm{kg}$ for RR2 corn hybrid DKC67-22. Overall aflatoxin levels in the ten corn hybrids tested were higher from inoculated soils than from non-inoculated soils, and varied significantly $(\mathrm{P} \leq 0.05)$ among the ten corn hybrids tested in the inoculated fields in comparison to the levels of aflatoxin among the same hybrids tested in the non-inoculated soil. Levels of aflatoxin were variable and no one hybrid or group of hybrids was consistent in the levels of aflatoxin contamination when grown in Tunica clay under all experimental conditions. 
Table 3. Analysis of variance (F values and P values) for the effects of year, cultivar, soil, and inoculation (Inoc) on aflatoxin $(\mu \mathrm{g} / \mathrm{kg})$ and fumonisin $(\mathrm{mg} / \mathrm{kg})$ on corn genetic background [(stacked gene hybrids with multiple Bt genes; Round-up Reddy, RR2; and non-GMO)] in sandy and clay soils under Mississippi delta conditions.

\begin{tabular}{|c|c|c|c|c|c|}
\hline \multirow{2}{*}{ Source effects } & \multirow{2}{*}{$\mathrm{DF}$} & \multicolumn{2}{|c|}{ Aflatoxin } & \multicolumn{2}{|c|}{ Fumonisin } \\
\hline & & F-Calc. & $\mathrm{P}$ & FCalc. & $\mathrm{P}$ \\
\hline Year & 1 & 32.27 & $* * *$ & 12.91 & ${ }^{* * *}$ \\
\hline Soil & 1 & 43.4 & $* * *$ & 2.88 & * \\
\hline Year $\times$ Soil & 1 & 59.17 & ${ }^{* * *}$ & 9.91 & ** \\
\hline Genetic background & 2 & 0.29 & NS & 1.27 & NS \\
\hline Year $\times$ Genetic background & 2 & 2.16 & NS & 0.73 & NS \\
\hline Soil × Genetic background & 2 & 0.3 & NS & 0.32 & NS \\
\hline Year $\times$ Soil $\times$ Genetic background & 2 & 2.38 & NS & 1.03 & NS \\
\hline Inoc & 1 & 7.03 & $* *$ & 7.95 & ** \\
\hline Year $\times$ Inoc & 1 & 0.01 & NS & 0.07 & NS \\
\hline Soil $\times$ Inoc & 1 & 1.06 & NS & 9.43 & ** \\
\hline Year $\times$ Soil $\times$ Inoc & 1 & 3.83 & * & 45.3 & ${ }^{* * *}$ \\
\hline Genetic background $\times$ Inoc & 2 & 0.17 & NS & 0.14 & NS \\
\hline Year $\times$ Genetic background $\times$ Inoc & 2 & 1.25 & NS & 0.61 & NS \\
\hline Soil $\times$ Genetic background $\times$ Inoc & 2 & 0.2 & NS & 0.13 & NS \\
\hline Year $\times$ Soil $\times$ Genetic background $\times$ Inoc & 2 & 0.56 & NS & 0.2 & NS \\
\hline Rep (Year) & & $1.24 \mathrm{E}-14$ & & 0 & \\
\hline Residual & & 27183 & & 6.4579 & \\
\hline
\end{tabular}

${ }^{*}$ Significance at $\mathrm{P} \leq 0.05 ;{ }^{* *}$ Significance at $\mathrm{P} \leq 0.01 ;{ }^{* * *}$ Significance at $\mathrm{P} \leq 0.001$.

Table 4. Aflatoxin contamination levels of ten irrigated corn hybrids representing three genotype classes grown on two sites, a Tunica Clay and a Bosket Fine Sandy Loam (FSL) near Stoneville, MS across 2011 and $2012^{\dagger}$.

\begin{tabular}{|c|c|c|c|c|c|}
\hline \multirow{3}{*}{ Hybrid } & \multirow{3}{*}{ Hybrid class } & \multicolumn{4}{|c|}{ Aflatoxin $(\mu \mathrm{g} / \mathrm{kg})$} \\
\hline & & \multicolumn{2}{|c|}{ Tunica clay } & \multicolumn{2}{|c|}{ Bosket FSL } \\
\hline & & Non-Inc ${ }^{\ddagger}$ & $\mathrm{Inc}^{\S}$ & Non-Inc ${ }^{\S}$ & $\mathrm{Inc}^{\S}$ \\
\hline 31P41 & Non & 14.6 & $21.5 b$ & $149.6 b$ & 154.9ab \\
\hline 33N56 & Non & 14.8 & $30.2 b$ & $91.6 \mathrm{~b}$ & 267ab \\
\hline 1615R & RR2 & 12.2 & $18.3 b$ & $115.4 \mathrm{~b}$ & 143.3ab \\
\hline $31 \mathrm{P} 40$ & RR2 & 4.9 & $0.1 \mathrm{~b}$ & $125.7 \mathrm{~b}$ & $329.9 \mathrm{ab}$ \\
\hline 33N55 & RR2 & 6.9 & $44.8 b$ & $129.4 b$ & $158.2 \mathrm{ab}$ \\
\hline DKC 67-22 & RR2 & 7.4 & 207.4a & $59.3 \mathrm{~b}$ & $118 b$ \\
\hline $31 G 96$ & Stacked & 1.4 & $22.9 b$ & $289.4 a$ & $335.9 a$ \\
\hline 31P42 & Stacked & 2.9 & $16.2 b$ & $136.8 \mathrm{~b}$ & $153.5 \mathrm{ab}$ \\
\hline DKC 66-96 & Stacked & 5 & $36.2 b$ & $114.2 \mathrm{~b}$ & $176.2 \mathrm{ab}$ \\
\hline DKC 67-21 & Stacked & 88.9 & 153.8ab & $43.1 \mathrm{~b}$ & $93.4 \mathrm{c}$ \\
\hline
\end{tabular}

${ }^{\dagger}$ Means of 4 replications and 2 years. ${ }^{\ddagger}$ Means are not significantly different. ${ }^{\S}$ Means within a column followed by the same letter or letters are not significantly different $\mathrm{P} \leq 0.05$. 
Aflatoxin levels of corn grown in Bosket FSL soil were higher ranging from $43.1 \mu \mathrm{g} / \mathrm{kg}$ for stacked corn hybrid DKC67-21 to $335.9 \mu \mathrm{g} / \mathrm{kg}$ for the stacked corn hybrid 31G96 under both non-inoculated and inoculated conditions compared with the overall levels of aflatoxin in Tunica clay soil (Table 4). Although there were significant differences $(\mathrm{P} \leq 0.05)$ in aflatoxin levels among hybrids in Bosket FSL soil, all hybrids had aflatoxins above the regulatory level of $20 \mu \mathrm{g} / \mathrm{kg}$.

The levels of fumonisin of the combined samples harvested in 2011 and 2012 are shown in Table 5 Fumonisin levels were less variable overall than aflatoxin levels ranging from 0.5 to $16.2 \mathrm{mg} / \mathrm{kg}$. Average fumonisin levels were about the same in all hybrids in both non-inoculated and inoculated fields both years (Table 5), and differences were highly significant $(\mathrm{P} \leq 0.05)$ among all hybrids. Fumonisin levels among all hybrids grown in non-inoculated and inoculated Bosket FSL soil type were not significantly different ranging from $1.2 \mathrm{mg} / \mathrm{kg}$ to $5.0 \mathrm{mg} / \mathrm{kg}$ (Table 5). Observations of fumonisin levels among the hybrids were similar to observations of aflatoxin levels among the hybrids. No single hybrid or group of hybrids stood out as resistant or susceptible.

Aflatoxin levels were quite different between 2011 and 2012, possibly due to temperature and rainfall conditions despite irrigation. Differences in aflatoxin levels were evident between 2011 and 2012 in grain samples from non-inoculated or inoculated treatments in Bosket FSL soil. The aflatoxin levels in the 2011 samples ranged from 237.5 to $339.9 \mu \mathrm{g} / \mathrm{kg}$ for non-inoculated and inoculated Bosket FSL soil, respectively, and were higher than aflatoxin levels from corn samples from the Tunica Clay soil (Table 6). Likewise, aflatoxin levels in the 2012 samples were lower than in 2011 samples and ranged from $11.8 \mu \mathrm{g} / \mathrm{kg}$ to $52.1 \mu \mathrm{g} / \mathrm{kg}$ for the noninoculated and inoculated field, respectively. The aflatoxin levels in harvested corn samples in 2011 and 2012 were lower in the non-inoculated Tunica Clay field, ranging from $15.2 \mu \mathrm{g} / \mathrm{kg}$ in 2012 to $15.9 \mu \mathrm{g} / \mathrm{kg}$ in 2011 .

Fumonisin levels in corn samples harvested from Tunica Clay and Bosket FSL soil types were inconsistent as far as non-inoculated and inoculated fields in 2011 and 2012 (Table 6). Fumonisin levels in samples from both non-inoculated and inoculated soils in the Tunica clay field in 2011 were almost identical at 2.3 and $2.2 \mathrm{mg} / \mathrm{kg}$, respectively. In 2012, the levels were significantly different at 0.3 and $4 \mathrm{mg} / \mathrm{kg}$, respectively $(\mathrm{P} \leq 0.05)$. Samples harvested from the non-inoculated and inoculated Bosket FSL fields were 2.9 and $6.0 \mathrm{mg} / \mathrm{kg}$ in 2011 and 2.6 and $0.6 \mathrm{mg} / \mathrm{kg}$ in 2012. Yields of the various corn hybrids used in this study were higher for all hybrids in the Tunica clay soil [12] compared to the same hybrids in the sandy loam Bosket FSL. During the course of the experiments, hybrids in the Tunica clay soil exhibited better plant growth and health (Bruns, Unpublished data).

Table 5. Fumonisin contamination levels of ten irrigated corn hybrids representing three genotype classes grown on two sites, a Tunica Clay and a Bosket Fine Sandy Loam (FSL) near Stoneville, MS across 2011 and $2012^{\dagger}$.

\begin{tabular}{|c|c|c|c|c|c|}
\hline \multirow{3}{*}{ Hybrid } & \multirow{3}{*}{ Class } & \multicolumn{4}{|c|}{ Fumonisin (mg/kg) } \\
\hline & & \multicolumn{2}{|c|}{ Tunica clay } & \multicolumn{2}{|c|}{ Bosket FSL } \\
\hline & & Non-Inc ${ }^{\S}$ & $\operatorname{Inc} c^{\S}$ & Non-Inc ${ }^{\S}$ & $\operatorname{Inc}^{\ddagger}$ \\
\hline 31P41 & Non & $1.1 \mathrm{bc}$ & $1.4 \mathrm{c}$ & 2.3 & 4.4 \\
\hline $33 N 56$ & Non & $2.0 \mathrm{~b}$ & $5.7 \mathrm{a}$ & 3.6 & 5 \\
\hline $1615 \mathrm{R}$ & RR2 & $0.6 \mathrm{c}$ & $2.1 \mathrm{bc}$ & 2.3 & 2.5 \\
\hline $31 \mathrm{P} 40$ & RR2 & $1.9 \mathrm{~b}$ & $1.6 \mathrm{c}$ & 2.9 & 3.2 \\
\hline $33 N 55$ & RR2 & $1.2 \mathrm{~b}$ & $3.7 \mathrm{~b}$ & 3.9 & 4.3 \\
\hline DKC 67-22 & RR2 & $0.5 \mathrm{c}$ & $2.3 \mathrm{bc}$ & 1.4 & 2.4 \\
\hline $31 \mathrm{G} 96$ & Stacked & $2.4 \mathrm{~b}$ & $5.9 \mathrm{a}$ & 3.1 & 2.4 \\
\hline 31P42 & Stacked & $16.2 \mathrm{a}$ & $2.4 \mathrm{bc}$ & 3.7 & 2.7 \\
\hline DKC 66-96 & Stacked & $1.8 \mathrm{~b}$ & $5.7 \mathrm{a}$ & 2.4 & 1.2 \\
\hline DKC 67-21 & Stacked & $0.5 \mathrm{c}$ & $2.4 \mathrm{bc}$ & 1.8 & 2.1 \\
\hline
\end{tabular}

${ }^{\dagger}$ Means of 4 replications and 2 years; ${ }^{\ddagger}$ Means are not significantly different; ${ }^{\S}$ Means within a column followed by the same letter or letters are not significantly different $\mathrm{P} \leq 0.05$. 
Table 6. Aflatoxin and Fumonisin contamination levels of irrigated corn hybrids grown on two sites, a Tunica Clay and a Bosket Fine Sandy Loam (FSL) Near Stoneville, MS across 2011 and $2012^{\dagger}$.

\begin{tabular}{|c|c|c|c|c|}
\hline \multirow[b]{3}{*}{ Year } & \multicolumn{4}{|c|}{ Aflatoxin $(\mu \mathrm{g} / \mathrm{kg})$} \\
\hline & \multicolumn{2}{|c|}{ Tunica clay } & \multicolumn{2}{|c|}{ Bosket FSL } \\
\hline & Non-Inc ${ }^{\ddagger}$ & $\operatorname{Inc} c^{\S}$ & Non-Inc ${ }^{\S}$ & $\mathrm{Inc}^{\S}$ \\
\hline 2011 & 15.9 & 7.6 & 237.5 & 339.9 \\
\hline \multirow[t]{3}{*}{2012} & 15.2 & 92.9 & 11.8 & 52.1 \\
\hline & \multicolumn{4}{|c|}{ Fumonisin (mg/kg) } \\
\hline & \multicolumn{2}{|c|}{ Tunica clay } & \multicolumn{2}{|c|}{ Bosket FSL } \\
\hline Year & Non-Inc ${ }^{\S}$ & $\operatorname{Inc}^{\S}$ & Non-Inc ${ }^{\ddagger}$ & $\mathrm{Inc}^{\S}$ \\
\hline 2011 & 2.3 & 2.2 & 2.9 & 6.0 \\
\hline 2012 & 0.3 & 4 & 2.6 & 0.6 \\
\hline
\end{tabular}

${ }^{\dagger}$ Means of 10 hybrids representing 3 genotypes and 4 replications. ${ }^{\ddagger}$ Means are not significantly different. ${ }^{\S}$ Means within a column are significantly different $\mathrm{P} \leq 0.05$.

The theory that reducing plant stress during the kernel-filling time will cause reductions in mycotoxin levels was tested in this research by evaluating if weather data during the 2011 and 2012 growing seasons might correlate with aflatoxin and fumonisin levels (Figure 1). Weather comparisons between the 2 years were significantly different in rainfall. For example, the maximum temperature in June, July, and August 2011 were 34.9, 35.4, and $35.4^{\circ} \mathrm{C}$, respectively, compared to $31.7^{\circ} \mathrm{C}, 33.7^{\circ} \mathrm{C}$, and $34.1^{\circ} \mathrm{C}$ in 2012 (Figure 1). Similar trends for rainfall were observed where the precipitation was lower during June, July, and August, resulting in a warmer and drier year in 2011 than in 2012, although the precipitation was higher early in the season in 2011 compared to 2012. These conditions may have created additional stress due to warmer and drier season, especially during the kernel-filling stage and contributed to much higher aflatoxin contamination in sandy soils. Field water holding capacity of sandy soils is lower than that of clay soils, consequently crops grown in sandy soil are more sensitive to drought stress even when the irrigation is used. Fumonisin levels in the corn samples did not consistently relate to weather conditions. Recently it was found that these hybrids did not yield as well in sandy soil, possibly due to drought stress even when they received adequate irrigation, (Bruns, unpublished data) compared to the same hybrids grown in clay soil [12] [25] [39]. In all cases corn grown in sandy loam soil had much higher levels of aflatoxin. None of the hybrids, conventional or stacked-gene, were clearly superior to the others in terms of aflatoxin levels. Some reports of hybrids with a Bt gene showed variable effects on mycotoxin levels. Some authors reported beneficial effects of hybrids, others did not [1] [40]-[43]. A multifaceted strategy to reduce mycotoxins appears to be necessary [44].

\section{Conclusion}

It is not clear at this time whether the benefits of stacked-gene hybrids justify the costs of their development [12]. To reach a conclusive recommendation, more research is required where more hybrids are tested across more years, geographic locations, and under irrigated and non-irrigated conditions.

\section{Acknowledgements}

We would like to thank Jeremy Kotowicz, Roderick Patterson, and Terry Johnson for their technical assistance. Mention of trade names or commercial products in this publication is solely for the purpose of providing specific information and does not imply recommendation or endorsement by the U.S. Department of Agriculture.

\section{References}

[1] Abbas, H.K., Zablotowicz, R.M., Weaver, M.A., Shier, W.T., Bruns, H.A., Bellaloui, N., Accinelli, C. and Abel, C.A. (2013) Implications of Bt Traits on Mycotoxin Contamination in Maize: Overview and Recent Experimental Results in 
Southern United States. Journal of Agriculture and Food Chemistry, 61, 11759-11770. http://dx.doi.org/10.1021/jf400754g

[2] Alstad, D.N. and Andow, D.A. (1995) Managing the Evolution of Insect Resistance to Transgenic Plants. Science, 268, 894-1896. http://dx.doi.org/10.1126/science.268.5219.1894

[3] Catangui, M.A. and Berg, R.K. (2006) Western Bean Cutworm, Striacosta albicosta (Smith) (Lepidoptera: Noctuidae), as a Potential Pest of Transgenic Cry1Ab Bacillus thuringiensis Corn Hybrids in South Dakota. Environmental Entomology, 35, 1439-1452. http://dx.doi.org/10.1093/ee/35.5.1439

[4] Estruch, J.J., Warren, G.W., Mullins, M.A., Nye, G.J., Craig, J.A. and Koziel, M.G. (1996) Vip3A, a Novel Bacillus thuringiensis Vegetative Insecticidal Protein with a Wide Spectrum of Activities against Lepidopteran Insects. Proceedings of the National Academy of Sciences of the United States of America, 93, 5389-5394. http://dx.doi.org/10.1073/pnas.93.11.5389

[5] George, Z. and Crickmore, N. (2012) Bacillus thuringiensis Applications in Agriculture. In: Sansinenea, E., Ed., Bacillus thuringiensis Biotechnology, Chapter 2, Springer Science +Business Media, New York, 19-39. http://dx.doi.org/10.1007/978-94-007-3021-2_2

[6] Huang, F., Leonard, B.R. and Gable, R.H. (2006) Comparative Susceptibility of European Corn Borer, Southwestern Corn Borer, and Sugarcane Borer (Lepidoptera: Crambidae) to Cry1Ab Protein in a Commercial Bt-Corn Hybrid. Journal of Economic Entomology, 99, 194-202. http://dx.doi.org/10.1093/jee/99.1.194

[7] Hutchison, W.D., Burkness, E.C., Mitchell, P.D., Moon, R.D., Leslie, T.W., Fleischer, S.J., Abrahamson, M., Hamilton, K.L., Steffey, K.L., Gray, M.E., Hellmich II, R.L., Kaster, V., Hunt, T.E., Wright, R.J., Pecinovsky, K.T., Rabaey, T.L., Flood, B.R. and Raun, E.S. (2010) Areawide Suppression of European Corn Borer with Bt Maize Reaps Savings to Non-Bt Maize Growers. Science, 330, 222-225. http://dx.doi.org/10.1126/science.1190242

[8] Lu, Y., Wu, K., Jiang, Y., Guo, Y. and Desneux, N. (2012) Widespread Adoption of Bt Cotton and Insecticide Decrease Promotes Biocontrol Services. Nature, 487, 362-365. http://dx.doi.org/10.1038/nature11153

[9] Martin, P. and Travers, R. (1989) Worldwide Abundance and Distribution of Bacillus thuringiensis Isolates. Applied and Environmental Entomology, 55, 2437-2442.

[10] Mugo, S.N., Mwimali, M., Taracha, C.O., Songa, J.M., Gichuki, S.T., Tende, R., Karaya, H., Bergvinson, D.J., Pellegrineschi, A. and Hoisington, D.A. (2011) Testing Public Bt Maize Events for Control of Stem Borers in the First Confined Field Trials in Kenya. African Journal of Biotechnology, 10, 4713-4718.

[11] Vaeck, M., Reynaert, A., Hofte, H., Jansens, S., Debeuckeleer, M., Dean, C., Zabeau, M., Vanmontagu, M. and Leemans, J. (1987) Transgenic Plants Protected from Insect Attack. Nature, 328, 33-37. http://dx.doi.org/10.1038/328033a0

[12] Bruns, H.A. (2014) Stacked-Gene Hybrids Were Not Found to Be Superior to Glyphosate Resistant or Non-GMO Corn Hybrids. Crop Management.

[13] Brewer, M. and Odvody, G. (2012) Contributions of Stacked-Trait Bt-Corn, Irrigation, and Hybrid Background on Aflatoxin, Ear Damage, and Yield under Varying Insect Pressure. http://www.corntechconf.org/CUTC/presentations.asp

[14] Abbas, H.K., Accinelli, C., Zablotowicz, R.M., Abel, C.A., Bruns, H.A., Dong, Y. and Shier, W.T. (2012) Dynamics of Mycotoxin and Aspergillus flavus Levels in Aging Bt and Non-Bt Corn Residues under Mississippi No-Till Conditions. Journal of Agriculture and Food Chemistry, 56, 7578-7585. http://dx.doi.org/10.1021/jf801771a

[15] Williams, W.P., Windham, G.L., Krakowsky, M.D., Scully, B.T. and Ni, X. (2010) Aflatoxin Accumulation in Bt and Non-Bt Maize Test Crosses. Journal of Crop Improvement, 24, 392-399. http://dx.doi.org/10.1080/15427528.2010.505111

[16] Wiatrak, P.J., Wright, D.L., Marois, J.J. and Wilson, D. (2005) Influence of Planting Date on Aflatoxin Accumulation in Bt, Non-Bt, and Tropical Non-Bt Hybrids. Agronomy Journal, 97, 440-445. http://dx.doi.org/10.2134/agronj2005.0440

[17] Dowd, P.F. (2000) Indirect Reduction of Ear Molds and Associated Mycotoxins in Bacillus thuringiensis in Corn under Controlled and Open Field Conditions: Utility and Limitations. Journal of Environmental Entomology, 93, 16691679. http://dx.doi.org/10.1603/0022-0493-93.6.1669

[18] Munkvold, G.P., Hellmich, R.L. and Rice, L.G. (1999) Comparison of Fumonisin Concentrations in Kernels of Transgenic Bt Maize Hybrids and Nontransgenic Hybrids. Plant Disease, 83, 130-138. http://dx.doi.org/10.1094/PDIS.1999.83.2.130

[19] Williams, W.P., Buckley, P.M. and Windham, G.L. (2002) Southwestern Corn Borer (Lepidoptera: Crambidae) Damage and Aflatoxin Accumulation in Maize. Journal of Economic Entomololy, 95, 1049-1053. http://dx.doi.org/10.1093/jee/95.5.1049

[20] Windham, G.L., Williams, W.P. and Davis, F.M. (1999) Effects of the Southwestern Corn Borer on Aspergillus flavus Kernel Infection and Aflatoxin Accumulation in Maize Hybrids. Plant Disease, 83, 535-540. 
http://dx.doi.org/10.1094/PDIS.1999.83.6.535

[21] Robens, J. and Cardwell, K. (2003) The Costs of Mycotoxin Management to the USA: Management of Aflatoxins in the United States. Journal of Toxicology: Toxin Reviews, 22, 139-152. http://dx.doi.org/10.1081/TXR-120024089

[22] Abbas, H.K. (Ed.) (2005) Aflatoxin and Food Safety. CRC Press, Boca Raton. http://dx.doi.org/10.1201/9781420028171

[23] Abbas, H.K., Zablotowicz, R.M., Shier, W.T., Johnson, B.J., Phillips, N.A., Weaver, M.A., Abel, C.A. and Bruns, H.A. (2015) Aflatoxin and Fumonisin in Corn (Zea mays) Infected by Common Smut Ustilago maydis. Plant Disease, 99, 1236-1240. http://dx.doi.org/10.1094/PDIS-03-14-0234-RE

[24] CAST (Council for Agriculture Science and Technology) (2003) Mycotoxins Risks in Plant, Animal, and Human Systems. Task Force Report 139, CAST, Ames.

[25] Abbas, H.K., Shier, W.T. and Cartwright, R.D. (2007) Effect of Temperature, Rain Fall, and Planting Date on Aflatoxin and Fumonisin Contamination in Commercial Bt and Non-Bt Corn Hybrids in Arkansas. Phytoprotection, 88, 41-50. http://dx.doi.org/10.7202/018054ar

[26] Abbas, H.K., Williams, W.P., Windham, G.L., Pringle Jr., J.C., Xie, W. and Shier, W.T. (2002) Aflatoxin and Fumonisin Contamination of Commercial Corn (Zea mays) Hybrids in Mississippi. Journal of Agriculture and Food Chemistry, 50, 5246-5254. http://dx.doi.org/10.1021/jf020266k

[27] Bruns, H.A. and Abbas, H.K. (2005) Responses of Short-Season Corn Hybrids to a Humid Sub-Tropical Environment. Agronomy Journal, 97, 446-451. http://dx.doi.org/10.2134/agronj2005.0446

[28] Bruns, H.A. and Abbas, H.K. (2006) Planting Date Effects on Bt and Non-Bt Corn in the Mid South USA. Agronomy Journal, 98, 100-106. http://dx.doi.org/10.2134/agronj2005.0143

[29] De la Campa, R., Hooker, D.C., Miller, J.D., Schaafsma, A.W. and Hammond, B.G. (2005) Modeling Effects of Environment, Insect Damage, and Bt Genotypes on Fumonisin Accumulation in Maize in Argentina and the Philippines. Mycopathologia, 159, 539-552. http://dx.doi.org/10.1007/s11046-005-2150-3

[30] Diener, U.L., Cole, R.J., Sanders, T.H., Payne, G.A., Lee, L.S. and Klich, M.A. (1987) Epidemiology of Aflatoxin Formation by Aspergillus flavus. Annual Review of Phytopathology, 25, 249-270. http://dx.doi.org/10.1146/annurev.py.25.090187.001341

[31] Payne, G.A. (1992) Aflatoxin in Maize. Critical Reviews in Plant Sciences, 10, 423-440. http://dx.doi.org/10.1080/07352689209382320

[32] Abbas, H.K., Wilkinson, J.R., Zablotowicz, R.M., Accinelli, C., Abel, C.A., Bruns, H.A. and Weaver, M.A. (2009) Ecology of Aspergillus flavus, Regulation of Aflatoxin Production and Management Strategies to Reduce Aflatoxin Contamination of Corn. Toxin Reviews, 2-3, 142-152. http://dx.doi.org/10.1080/15569540903081590

[33] King, E.D., Bassi, A.B., Ross, D.C. and Druebbisch, B. (2011) An Industry Perspective on the Use of Atoxigenic Strains of Aspergillus flavus as Biological Control Agents and the Significance of Cyclopiazonic Acid. Toxin Reviews, 30, 33-41. http://dx.doi.org/10.3109/15569543.2011.588818

[34] National Toxicology Program (NTP) (2001) Toxicology and Carcinogenesis Studies of Fumonisin B1 in F344/N Rats and B6C3F1 Mice (Feed Studies). Department of Health \& Human Services, Public Health Service, NTP, Central Data Management, Research Triangle Park.

[35] Accinelli, C., Abbas, H.K., Vicari, A. and Shier, W.T. (2014) Aflatoxin Contamination of Corn under Different Agro-Environmental Conditions and Biocontrol Applications. Crop Protection, 63, 9-14. http://dx.doi.org/10.1016/j.cropro.2014.04.021

[36] Plattner, R.D. (1999) HPLC/MS Analysis of Fusarium Mycotoxins, Fumonisins and Deoxynivalenol. Natural Toxins, 7, 365-370. http://dx.doi.org/10.1002/1522-7189(199911/12)7:6<365::AID-NT85>3.0.CO;2-0

[37] Muscarella, M., Magro, S.L., Nardiello, D., Palermo, C. and Centonze, D. (2008) Development a New Analytical Method for the Determination of Fumonisin B1 and B2 in Food Products Based on High Performance Liquid Chromatography and Fluorimetric Detection with Post-Column Derivatization. Journal of Chromatography A, 1203, 88-93. http://dx.doi.org/10.1016/j.chroma.2008.07.034

[38] MSUcares (2014) http://msucares.com/crops/soybeans/index.html

[39] Kebede, H., Abbas, H.K., Fisher, D.K. and Bellaloui, N. (2012) Relationship between Aflatoxin Contamination and Physiological Responses of Corn Plants under Drought and Heat Stress. Toxins, 4, 1385-1403. http://dx.doi.org/10.3390/toxins4111385

[40] Hammond, B.G., Campell, K.W., Pilcher, C.D., Degooyer, T.A., Robinson, A.E., McMillen, B.L., Spangler, S.M., Riordan, S.G., Rice, L.G. and Richard, J.L. (2004) Lower Fumonisin Mycotoxin Levels in the Grain of Bt Corn Grown in the United States in 2000-2002. Journal of Agriculture and Food Chemistry, 52, 1390-1397.

http://dx.doi.org/10.1021/jf030441c 
[41] Folcher, L., Delus, M., Marenque, E., Jarry, M., Weissenberger, A., Eychenne, N. and Regnault-Roger, C. (2010) Lower Mycotoxin Levels in Bt Maize Grain. Agronomy and Sustainable Development, 30, 711-719. http://dx.doi.org/10.1051/agro/2010005

[42] Ostry, V., Ovesna, J., Skarkova, J., Pouchova, V. and Ruprich, J. (2010) A Review on Comparative Data Concerning Fusarium Mycotoxins in Bt Maize and Non-Bt Isogenic Maize. Mycotoxin Research, 26, 141-145. http://dx.doi.org/10.1007/s12550-010-0056-5

[43] Schaafsma, A.W., Hooker, D.C., Baute, T.S. and Illincie-Tamburic, L. (2002) Effect of Bt-Corn Hybrids on Deoxynivalenol Content in Grain at Harvest. Plant Disease, 86, 1123-1126. http://dx.doi.org/10.1094/PDIS.2002.86.10.1123

[44] Tedford, E. (2012) Development and Refinement of Afla-Guard for Reduction of Aflatoxins in Corn in the US 2012. http://www.corntechconf.org/CUTC/presentations.asp 